\title{
Effects of Synthetic Trypsin Inhibitors on the Growth of Escherichia coli
}

\author{
Munetoshi Kato, Takaji IrIsawa and Mutumi Muramatu* \\ Faculty of Pharmacy, Tokushima Bunri University, Yamashiro-cho, Tokushima-shi, Tokushima 770, Japan. \\ Received August 7, 1992
}

\begin{abstract}
The inhibitory effects of various aromatic esters of trans-4-guanidinomethylcyclohexanecarboxylic acid (GMCHA), potent trypsin inhibitors, on the growth of Escherichia coli were examined and the effects were compared with those of well known synthetic trypsin inhibitors. Various GMCHA esters strongly inhibited the growth of $E$. coli and their effects were markedly affected by the species and position of substitution on the phenyl nucleus of the GMCHA phenyl esters. No correlation was observed between the effects on the growth of $E$. coli and $K_{\mathrm{i}}$ 's for trypsin. Inhibitory effects of benzamidine, phenylmethane sulfonylfuoride and diisopropyl fluorophosphate were less than $10 \%$ at $200 \mu \mathrm{M}$. 4-tert-Butylphenyl ester of GMCHA (GMCHA-OPh ${ }^{t} \mathrm{Bu}$ ), a representative of various GMCHA esters, dose-dependently inhibited the growth of $E$. coli and the growth inhibition was preceded by a dose- and time-dependent inhibition of DNA synthesis. Tosyl-L-lysine chloromethyl ketone (TLCK) and pentamidine isethionate, potent trypsin inhibitors, also dose-dependently inhibited the growth of $E$. coli and the DNA synthesis. However, their effects were transient and disappeared after a short while. These results indicate that the effects of TLCK and pentamidine isethionate differ from those of GMCHA esters. GMCHA-OPh ${ }^{t} \mathrm{Bu}$ and pentamidine isethionate also inhibited RNA and protein synthesis.
\end{abstract}

Keywords trypsin inhibitor; Escherichia coli; cell growth

\section{Introduction}

One of the most promising approaches to the regulation mechanism of a cell cycle is to find a suitable and specific inhibitor which blocks a specific event, such as DNA replication and cell division, whithout any effect on other events in the cell cycle process. Participation of intracellular proteinase in various cellular functions in Escherichia coli has been reported by many workers: rapid degradation of abnormal proteins or accelerated breakdown of normal cell proteins by starvation, ${ }^{1-3)}$ processing of secretory and membrane proteins, ${ }^{4,5)}$ utilization of exogeneous peptides, ${ }^{6)}$ the degradation of colicins, ${ }^{7,8)}$ viral morphogenesis, ${ }^{2,7)}$ and the selective inactivation of certain regulatory proteins. ${ }^{2,9)}$ Many workers have reported the effects of various protease inhibitors on various cell functions and on the growth of E. coli. $^{10-14)}$

Muramatu and Fujii reported that $\omega$-amino and $\omega$-guanidino acid esters strongly inhibited trypsin-like proteinases, ${ }^{15,16)}$ and Mori et al. ${ }^{17)}$ reported that trans-4-guanidinomethylcyclohexanecarboxylic acid 4-tert-butylphenyl ester (GMCHA-OPh${ }^{t} \mathrm{Bu}$ ) competitively inhibited trypsin and suppressed the growth of HeLa cells. Kozaki et $a l .{ }^{18)}$ reported that $\mathrm{GMCHA}-\mathrm{OPh}^{t} \mathrm{Bu}$ had no effect on any events in the first $S, G 2$ and $M$ phases, such as the incorporation of $\left[\right.$ methyl $\left.-{ }^{3} \mathrm{H}\right]$ thymidine into DNA, the increase in the cell concentration and the appearance of trypsin-like proteinase activity. However, GMCHA-OPh ${ }^{t} \mathrm{Bu}$ retarded the onset of the second $S$ phase and the various events in the second S, G2 and M phases for $3 \mathrm{~h}$. These results stimulated us to investigate the inhibitory effects of various esters of trans-4-guanidinomethylcyclohexanecarboxylic acid (GMCHA) on the growth of $E$. coli.

This paper reports that various aromatic esters of GMCHA, competitive inhibitors of trypsin, strongly inhibit the growth of $E$. coli, and their effects may be due to the inhibition of DNA synthesis, suggesting that their effects differ from those by well known trypsin inhibitors, such as tosyl-L-lysine chloromethyl ketone (TLCK) and pentamidine isethionate.
Materials and Methods

Materials 4-Chloro-2-isopropyl-5-methylphenyl, 4-biphenyl, 4-benzyloxycarbonylethylphenyl, 4-benzyloxycarbonylphenyl, 3-benzyloxycarbonylphenyl, 2,4,6-trichlorophenyl, 4-tert-butylphenyl, 4-phenyloxycarbonylphenyl, 2-isopropyl-5-methylphenyl, 2-biphenyl, 2-benzyloxycarbonylphenyl, 2,4-dichlorophenyl, 4-iodophenyl, 4-bromophenyl, 2-cyanophenyl, 2-phenyloxycarbonylphenyl, 4-ethylphenyl, 4-methylphenyl and phenyl esters of GMCHA were from Nippon Chemiphar Co., Ltd., Tokyo, as hydrochlorides. TLCK was from Nacalai Tesque Inc., Kyoto, and pentamidine isethionate was from Sigma Chemical Co., St. Louis. [methyl- $\left.{ }^{3} \mathrm{H}\right]$ Thymidine $(85 \mathrm{Ci} / \mathrm{mmol}),\left[5-{ }^{3} \mathrm{H}\right]$ uridine $(29 \mathrm{Ci} / \mathrm{mmol})$ and L- $\left[4,5-{ }^{3} \mathrm{H}\right]$ leucine $(160 \mathrm{Ci} / \mathrm{mmol})$ were from Amersham International plc, Buckinghamshire. $N^{\alpha}$-Benzoyl-DL-arginine $p$-nitroanilide hydrochloride was from the Protein Research Foundation, Osaka. Nutrient broth, nutrient agar, brain heart infusion (BHI) broth and $\mathrm{BHI}$ agar were from Nissui Pharmaceutical Co., Tokyo. Glucose minimum medium was prepared according to Davis and Mingioli. ${ }^{19)}$

$E$. coli strains IFO 3301 and $K \lambda$ s were from Prof. Fukui, Department of Oral Microbiology and Immunology, School of Dentistry, Tokushima University. E. coli strains IAM 1132, K-12 IAM 1264 and K-12 W 3110 were from Dr. Takahashi, Godo Shusei Co., Tokyo.

Inhibition of Trypsin Activity Inhibitory effects of various esters of GMCHA on tryptic activity were examined with $N^{\alpha}$-benzoyl-DL-arginine $p$-nitroanilide as a substrate, and $K_{\mathrm{i}}$ 's were calculated from the Lineweaver-Burk plots as described previously. ${ }^{17)}$

Growth of $\boldsymbol{E}$. coli Volumes of $5 \mathrm{ml}$ of nutrient broth medium at $\mathrm{pH}$ 7.0 containing various concentrations of an inhibitor were mixed with $0.1 \mathrm{ml}$ of $E$. coli suspension containing $2 \times 10^{5} \mathrm{cells} / \mathrm{ml}$, and incubated for $7 \mathrm{~h}$ at $37^{\circ} \mathrm{C}$ with shaking. After incubation, a mixture of $0.1 \mathrm{ml}$ of each E. coli culture diluted to $10^{3}$ to $10^{5}$-fold and $8 \mathrm{ml}$ of nutrient agar were spread on $90 \mathrm{~mm}$ agar plates, and incubated overnight at $37^{\circ} \mathrm{C}$. The resulting colonies were counted. Values were given as an average of five plates with standard errors. Similar experiments were performed with glucose minimum medium or BHI medium. In the experiments with glucose minimum medium the incubation period was $16 \mathrm{~h}$ at $37^{\circ} \mathrm{C}$. $\mathrm{IC}_{50}$ was defined as an inhibitor concentration for $50 \%$ inhibition of colony formation.

A volume of $40 \mathrm{ml}$ of E. coli K-12 IAM 1264 suspension attained stationary state was added to $360 \mathrm{ml}$ of glucose minimum medium and the mixture was incubated with stirring at $37^{\circ} \mathrm{C}$ with or without inhibitor. At one-hour intervals $3 \mathrm{ml}$ samples of the growing cell suspension were withdrawn, and the turbidity was determined at $600 \mathrm{~nm}$.

Uptake of $\left[{ }^{3} \mathrm{H}\right]$ Thymidine into DNA The uptake of $\left[{ }^{3} \mathrm{H}\right]$ thymidine into DNA was determined as described by Joseleau-Petit $e t$ al. ${ }^{20)} \mathrm{A}$ volume of $0.4 \mathrm{ml}$ of the growing $E$. coli suspension was withdrawn and incubated with $20 \mu \mathrm{l}$ of $\left[{ }^{3} \mathrm{H}\right]$ thymidine $(100 \mu \mathrm{Ci} / \mathrm{ml})$ for $5 \mathrm{~min}$ at $37^{\circ} \mathrm{C}$. The reaction was stopped by adding $0.4 \mathrm{ml}$ of $10 \%$ trichloroacetic acid. After $30 \mathrm{~min}$, precipitates were collected on a $0.45 \mu \mathrm{m}$ Millipore filter and rinsed with 
$5 \%$ trichloroacetic acid. Filters were dreid and counted in Scintisol EX-H (Dojin Laboratories, Kumamoto).

Uptake of $\left[5^{-3} \mathrm{H}\right]$ Uridine into RNA A volume of $0.4 \mathrm{ml}$ of the growing E. coli suspension was withdrawn and incubated with a mixture of $20 \mu \mathrm{l}$ of $\left[5-{ }^{3} \mathrm{H}\right]$ uridine $(100 \mu \mathrm{Ci} / \mathrm{ml})$ and $20 \mu$ of cold uridine $(100 \mu \mathrm{g} / \mathrm{ml})$ for $5 \mathrm{~min}$ at $37^{\circ} \mathrm{C}$. The reaction was stopped by adding $0.4 \mathrm{ml}$ of $10 \%$ trichloroacetic acid. After $30 \mathrm{~min}$, precipitates were collected on a $0.45 \mu \mathrm{m}$ Millipore filter and treated as described.

Incorporation of $\mathrm{L}-\left[4,5-{ }^{3} \mathrm{H}\right]$ Leucine into Protein A volume of $0.4 \mathrm{ml}$ of the growing $E$. coli suspension was incubated with a mixture of $20 \mu \mathrm{l}$ of L-[4,5 $\left.{ }^{3} \mathrm{H}\right]$ leucine $(100 \mu \mathrm{Ci} / \mathrm{ml})$ and $20 \mu \mathrm{l}$ of cold L-leucine $(100 \mu \mathrm{g} / \mathrm{ml})$ for $5 \mathrm{~min}$ at $37^{\circ} \mathrm{C}$. The labeling was terminated by the addition of an equal volume of $10 \%$ trichloroacetic acid and heated in a boiling water bath for $15 \mathrm{~min}$. The resulting precipitates were collected using a Millipore filter, and rinsed twice with $5 \%$ trichloroacetic acid and once with water. The filters were dried and counted in Scintisol EX-H.

\section{Results}

Effects of GMCHA Esters on the Growth of $E$. coli The effects of 4-biphenyl, 4-tert-butylphenyl and 2-benzyloxycarbonylphenyl esters of GMCHA on the growth of $E$. coli K-12 IAM 1264 in nutrient broth medium were examined by counting viable cells (Fig. 1). Inhibitor concentrations for a $50 \%$ inhibition $\left(\mathrm{IC}_{50}\right)$ of 4-biphenyl, 4-tert-butylphenyl and 2-benzyloxycarbonylphenyl esters of GMCHA were 26,45 and $87 \mu \mathrm{M}$, respectively, and their concentrations for $100 \%$ inhibition $\left(\mathrm{IC}_{100}\right)$ were 40,90 and $140 \mu \mathrm{M}$, respectively. At inhibitor concentrations for $100 \%$ inhibition no increases in turbidity were observed after $24 \mathrm{~h}$ incubation.

Table I shows IC $_{50}$ 's and IC $_{100}$ 's of various GMCHA esters on the growth of $E$. coli. IC $_{50}$ 's and IC $_{100}$ 's were determined as shown in Fig. 1. Among the esters tested, 4-chloro-2-isopropyl-5-methylphenyl and 4-biphenyl esters were strongly inhibitory, their IC $_{50}$ 's being 21 and $26 \mu \mathrm{M}$, respectively, and their $\mathrm{IC}_{100}$ 's being 30 and $40 \mu \mathrm{M}$, respectively. GMCHA itself, phenol and substituted phenols were not inhibitory even at $200 \mu \mathrm{M}$. The parent compound, phenyl ester of GMCHA, was weakly inhibitory (about $22 \%$ inhibition at $200 \mu \mathrm{M}) . K_{\mathrm{i}}$ 's of various esters of GMCHA for trypsin are also shown in Table I. $K_{\mathrm{i}}$ values of these esters were 29 to $325 \mu \mathrm{M}$, although no relationship between the inhibitory effects on trypsin and those on growth of $E$. coli was obtained. Inhibitory effects of protease inhibitors,

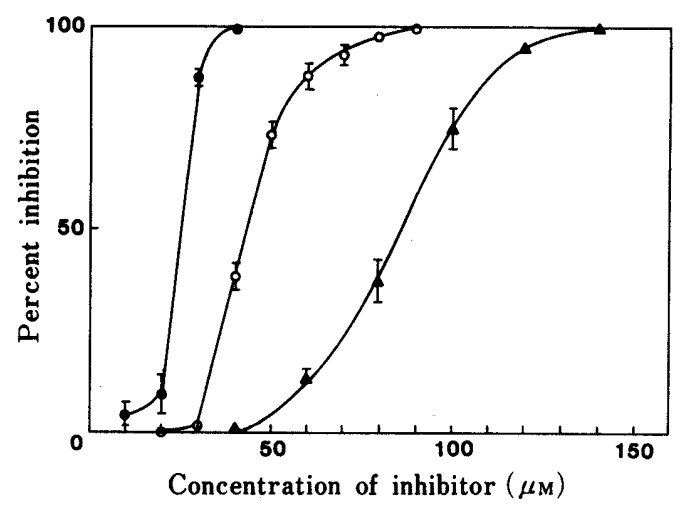

Fig. 1. Inhibitory Effects of 4-Biphenyl, 4-tert-Butylphenyl and 2Benzyloxycarbonylphenyl Esters of GMCHA on the Growth of $E$. coli

Volumes of $5 \mathrm{ml}$ of nutrient broth medium at $\mathrm{pH} 7.0$ containing various concentrations of an inhibitor were mixed with $0.1 \mathrm{ml}$ of $E$. coli K-12 IAM 1264 suspension containing $2 \times 10^{5} \mathrm{cells} / \mathrm{ml}$, and incubated at $37^{\circ} \mathrm{C}$ for $7 \mathrm{~h}$ with shaking. Viable cells were counted by colony counting on agar plates. Each point represents an average of five plates with standard errors. Vertical bars represent standard errors. - -, 4-biphenyl ester; - O-, GMCHA-OPh ${ }^{2} \mathrm{Bu} ;-\mathbf{A}-$, 2-benzyloxycarbonylphenyl ester. such as benzamidine, phenylmethane sulfonylfuoride and diisopropyl fluorophosphate, were less than $10 \%$ at $200 \mu \mathrm{M}$.

The relationship between the effect of GMCHA-OPh ${ }^{t} \mathrm{Bu}$ on the growth of $E$. coli and on the cell concentration was examined in nutrient broth medium. Various concentrations of $\mathrm{GMCHA}-\mathrm{OPh}^{t} \mathrm{Bu}$ were added to the medium containing $4 \times 10^{3}, 4 \times 10^{5}$ and $4 \times 10^{6}$ cells $/ \mathrm{ml}$, and the mixtures were incubated for $7,4.5$ and $3.5 \mathrm{~h}$, respectively, at $37^{\circ} \mathrm{C}$ with shaking. Without GMCHA-OPh ${ }^{t} \mathrm{Bu}$, cell numbers increased to approximately $2 \times 10^{8} \mathrm{cells} / \mathrm{ml}$ after each incubation time. Figure 2 represents the results. $\mathrm{IC}_{50}$ 's for each cell concentration of $4 \times 10^{3}, 4 \times 10^{5}$ and $4 \times 10^{6}$ cells $/ \mathrm{ml}$ were 45, 51 and $60 \mu \mathrm{M}$, respectively. Although the inhibitory effects of GMCHA-OPh ${ }^{t} \mathrm{Bu}$ decreased with increases in the

TABLE I. Inhibitory Effects of Various GMCHA Esters on Growth of E. coli and $K_{\mathrm{i}}$ 's for Trypsin

\begin{tabular}{|c|c|c|c|}
\hline \multirow{2}{*}{ Ester of GMCHA } & \multicolumn{3}{|c|}{ Inhibitory effects } \\
\hline & $\mathrm{IC}_{50}(\mu \mathrm{M})$ & $\mathrm{IC}_{100}(\mu \mathrm{M})$ & $K_{\mathrm{i}}(\mu \mathrm{M})$ \\
\hline $\begin{array}{l}\text { 4-Chloro-2-isopropyl-5-methyl- } \\
\text { phenyl }\end{array}$ & 21 & 30 & 35 \\
\hline 4-Biphenyl & 26 & 40 & 54 \\
\hline 4-Benzyloxycarbonylethylphenyl & 36 & 50 & 29 \\
\hline 4-Benzyloxycarbonylphenyl & 42 & 60 & 45 \\
\hline 3-Benzyloxycarbonylphenyl & 43 & 60 & 45 \\
\hline 2,4,6-Trichlorophenyl & 44 & 60 & 273 \\
\hline 4-tert-Butylphenyl & 45 & 90 & 38 \\
\hline 4-Phenyloxycarbonylphenyl & 64 & 100 & 103 \\
\hline 2-Isopropyl-5-methylphenyl & 68 & 120 & 325 \\
\hline 2-Biphenyl & 74 & 130 & 187 \\
\hline 2-Benzyloxycarbonylphenyl & 87 & 140 & 56 \\
\hline 2,4-Dichlorophenyl & 92 & 140 & 46 \\
\hline 4-Iodophenyl & 105 & $>200$ & 51 \\
\hline 4-Bromophenyl & 135 & $>200$ & 113 \\
\hline 2-Cyanophenyl & 142 & $>200$ & 85 \\
\hline 2-Phenyloxycarbonylphenyl & 153 & $>200$ & 56 \\
\hline 4-Ethylphenyl & 167 & $>200$ & 48 \\
\hline 4-Methylphenyl & $>200$ & $>200$ & 78 \\
\hline Phenyl & $>200$ & $>200$ & 110 \\
\hline
\end{tabular}

Inhibitory effects of various GMCHA esters on growth of $E$. coli K-12 IAM 1264 were examined in nutrient broth medium and IC $_{50}$ 's and IC $_{100}$ 's were determined as described in Fig. 1. Inhibitory effects of various esters of GMCHA on tryptic activity were examined with $N^{\alpha}$-benzoyl-DL-arginine $p$-nitroanilide as a substrate, and $K_{i}$ 's were calculated from the Lineweaver-Burk plots.

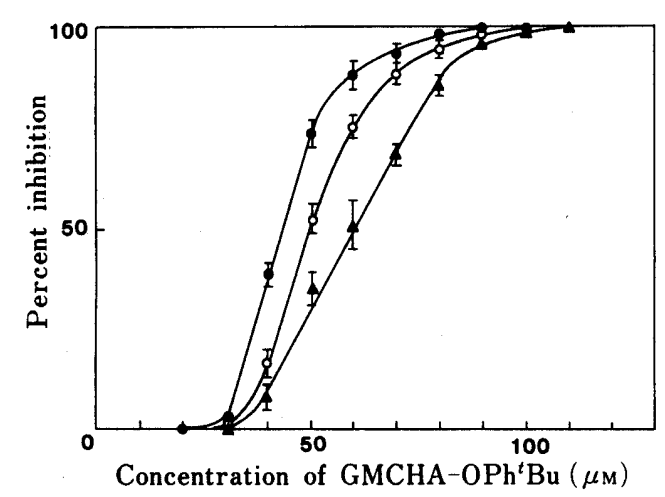

Fig. 2. Relationship between Inhibitory Effects of GMCHA-OPh ${ }^{t} \mathrm{Bu}$ on Growth of $E$. coli and on Cell Concentration

Volumes of $5 \mathrm{ml}$ of nutrient broth medium containing various concentrations of GMCHA-OPh ${ }^{t}$ Bu with $4 \times 10^{3}, 4 \times 10^{5}$ and $4 \times 10^{6}$ cells $/ \mathrm{ml}$ of $E$. coli $\mathrm{K}-12$ IAM 1264 were incubated at $37^{\circ} \mathrm{C}$ for $7,4.5$ and $3.5 \mathrm{~h}$, respectively, with shaking. Viable cells were counted by colony counting on agar plates. Each point represents an average of five plates with standard errors. Vertical bars represent standard errors. $4 \times 10^{3}$ cells $/ \mathrm{ml} ;-\mathrm{O}-, 4 \times 10^{5} \mathrm{cells} / \mathrm{ml} ;-\Delta-, 4 \times 10^{6} \mathrm{cells} / \mathrm{ml}$. 
TABLE II. Effects of GMCHA-OPh ${ }^{t} \mathrm{Bu}$ on Growth of Various Strains of $E$. coli

\begin{tabular}{lccc}
\hline \hline \multirow{2}{*}{$\begin{array}{c}\text { Strains of } \\
\text { E. coli }\end{array}$} & \multicolumn{3}{c}{$\mathrm{IC}_{50}(\mu \mathrm{M})$} \\
\cline { 2 - 4 } & $\begin{array}{c}\text { BHI } \\
\text { medium }\end{array}$ & $\begin{array}{c}\text { Nutrient broth } \\
\text { medium }\end{array}$ & $\begin{array}{c}\text { Glucose minimum } \\
\text { medium }\end{array}$ \\
\hline K $\lambda$ s & 14 & 14 & \\
IFO 3301 & 44 & 44 & \\
IAM 1132 & 41 & & 41 \\
K-12 IAM 1264 & 44 & 45 & \\
K-12 W 3110 & 49 & &
\end{tabular}

$E$ coli strains $K \lambda$ s, IFO 3301, IAM 1132, K-12 IAM 1264 and K-12 W 3110 were grown in each $\mathrm{BHI}$, nutrient broth and glucose minimum media and the effects of GMCHA-OPh ${ }^{t} \mathrm{Bu}$ on the growth of these strains were examined as described in Fig. 1.

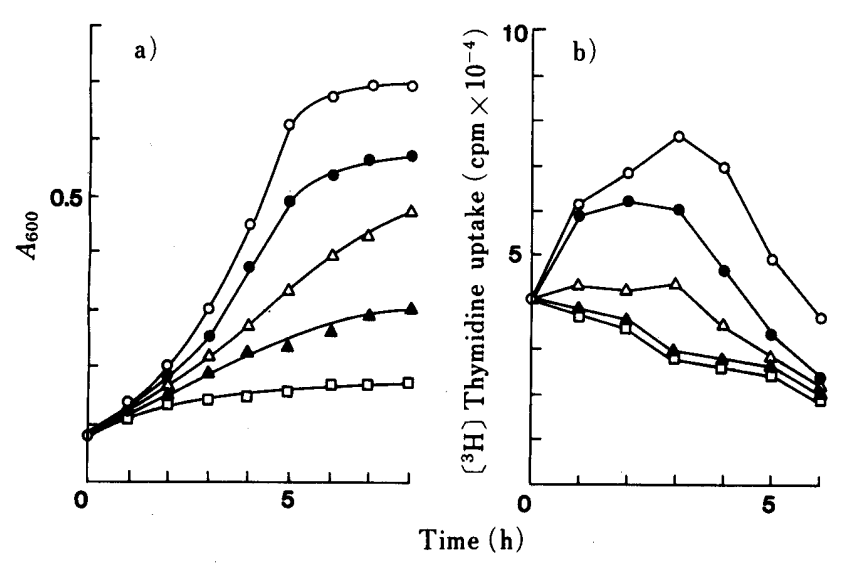

Fig. 3. Inhibitory Effects of GMCHA-OPh ${ }^{t} \mathrm{Bu}$ on Growth of E. coli and on the Uptake of $\left[{ }^{3} \mathrm{H}\right]$ Thymidine into DNA

A volume of $40 \mathrm{ml}$ of $E$. coli K-12 IAM 1264 suspension attained stationary state was added to $360 \mathrm{ml}$ of glucose minimum medium and incubated with stirring at $37^{\circ} \mathrm{C}$ with and without GMCHA-OPh ${ }^{t} \mathrm{Bu}$. a) The inhibitory effect on growth of $E$. coli was determined by turbidity measurement at $600 \mathrm{~nm}$. b) The inhibitory effect on the uptake of $\left[{ }^{3} \mathrm{H}\right]$ thymidine into DNA was determined by counting the radioactivity in cold trichloroacetic acid precipitable material after incubating the cells at $37^{\circ} \mathrm{C}$ for $5 \mathrm{~min}$ with $4.76 \mu \mathrm{Ci} / \mathrm{ml}$ of $\left[{ }^{3} \mathrm{H}\right]$ thymidine. - $\mathrm{O}$-, without GMCHA-OPht ${ }^{\mathrm{B} u}$; $-\longrightarrow$, with $27 \mu \mathrm{M} ;-\triangle-$, with $41 \mu \mathrm{M} ;-\Delta-$, with $54 \mu \mathrm{M} ;-\square-$, with $81 \mu \mathrm{M}$ of $\mathrm{GMCHA}-\mathrm{OPh}^{t} \mathrm{Bu}$.

cell concentrations, the extent of the decreases were small.

Effects of GMCHA-OPh ${ }^{t} \mathrm{Bu}$ on the growth of various strains of $E$. coli, such as $K \lambda$ s, IFO 3301, IAM 1132, K-12 W 3110 , were examined in BHI, nutrient broth or glucose minimum medium. GMCHA-OPh ${ }^{t} \mathrm{Bu}$ was strongly inhibitory on the growth of various strains of $E$. coli and its $\mathrm{IC}_{50}$ 's were as shown in Table II. The effect was most marked on strain $K \lambda$ s, the $\mathrm{IC}_{50}$ being $14 \mu \mathrm{M}$ in both the BHI and in the nutrient broth media. IC $_{50}$ 's for other strains were in the range of 40 to $50 \mu \mathrm{M}$. These results show that there is no significant difference between the different culture media.

Effects of GMCHA-OPh ${ }^{t} \mathrm{Bu}$ on Growth, and DNA, RNA and Protein Syntheses The effects of GMCHA-OPh ${ }^{t} \mathrm{Bu}$, which was selected as a representative of GMCHA esters, on the growth of $E$. coli K-12 IAM 1264 and the uptake of $\left[{ }^{3} \mathrm{H}\right]$ thymidine into DNA were examined. The growth of $E$. coli was determined by an increase in turbidity at $600 \mathrm{~nm}$. GMCHA-OPh ${ }^{t} \mathrm{Bu}$ dose-dependently suppressed the growth, and at a concentration of $81 \mu \mathrm{M}$ the cell growth was completely suppressed (Fig. 3a).

Figure $3 \mathrm{~b}$ shows the effect of GMCHA-OPh ${ }^{t} \mathrm{Bu}$ on the uptake of $\left[{ }^{3} \mathrm{H}\right]$ thymidine into DNA. Without GMCHA-

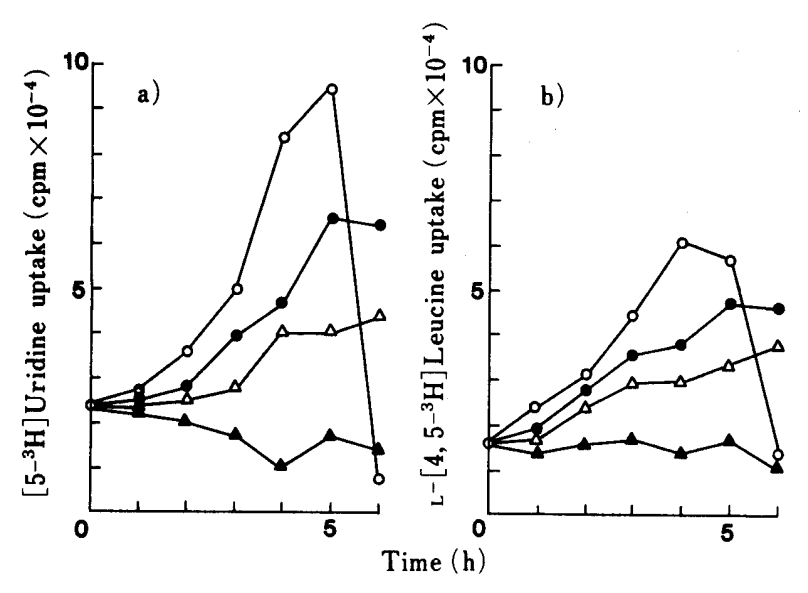

Fig. 4. Inhibitory Effects of GMCHA-OPh ${ }^{t} \mathrm{Bu}$ on RNA and Protein Syntheses

Experimental conditions were as described in Fig. 3. a) The inhibitory effects of GMCHA-OPh ${ }^{t} \mathrm{Bu}$ was determined by counting the radioactivity in cold trichloroacetic acid-precipitable materials after incubation at $37^{\circ} \mathrm{C}$ for $5 \mathrm{~min}$ with $4.56 \mu \mathrm{Ci} / \mathrm{ml}$ of $\left[5-{ }^{3} \mathrm{H}\right]$ uridine. b) The inhibitory effects of $\mathrm{GMCHA}-\mathrm{OPh}^{2} \mathrm{Bu}$ was determined by counting the radioactivity in hot trichloroacetic acid-precipitable material after incubation at $37^{\circ} \mathrm{C}$ for $5 \mathrm{~min}$ with $4.56 \mu \mathrm{Ci} / \mathrm{ml}$ of $\mathrm{L}-\left[4,5-{ }^{3} \mathrm{H}\right]$ leucine. $-\mathrm{O}-$, without inhibitor; $-\bullet-$, with $27 \mu \mathrm{M} ;-\triangle-$, with $41 \mu \mathrm{M} ;-\Delta-$, with $54 \mu \mathrm{M}$ of GMCHA-OPh ${ }^{t} \mathrm{Bu}$.

$\mathrm{OPh}^{t} \mathrm{Bu}$ the incorporation increased time-dependently and attained a maximum after $3 \mathrm{~h}$ and decreased after $4 \mathrm{~h}$. These results indicate that a decrease in the incorporation of $\left[{ }^{3} \mathrm{H}\right]$ thymidine into DNA precedes a decrease in the growth. GMCHA-OPh ${ }^{t} \mathrm{Bu}$ dose-dependently suppressed the uptake of $\left[{ }^{3} \mathrm{H}\right]$ thymidine into DNA. The addition of the above $54 \mu \mathrm{M}$ of the inhibitor immediately reduced the uptake. The results shown in Figs. 3a and $3 b$ suggest that the suppression of the cell growth by $\mathrm{GMCHA}-\mathrm{OPh}^{t} \mathrm{Bu}$ is due to the inhibition of DNA replication, because the suppression of DNA replication by the inhibitor precedes that of cell growth.

Figures $4 a$ and $4 b$ show the effects of GMCHA-OPh ${ }^{t} \mathrm{Bu}$ on RNA and protein syntheses. Without inhibitor RNA, synthesis rapidly increased after $1 \mathrm{~h}$ and reached a maximum after $5 \mathrm{~h}$, followed by a rapid fall (Fig. 4a). These results are similar to the patterns observed in the growth of $E$. coli (see Fig. 3a). GMCHA-OPh ${ }^{t} \mathrm{Bu}$ dose-dependently suppressed the RNA synthesis, and the effect was similar to that on cell growth (see Fig. 3a).

Similar effects were observed on protein synthesis (Fig. 4b). Without inhibitor protein, synthesis rapidly increased and reached a maximum after 4 to $5 \mathrm{~h}$, followed by a rapid decrease. These results were closely related to RNA synthesis and reflected the cell growth. GMCHA-OPh ${ }^{t} \mathrm{Bu}$ dose-dependently suppressed the protein synthesis, and the results were similar to those on cell growth and RNA synthesis.

Effects of TLCK and Pentamidine Isethionate on Growth, and DNA, RNA and Protein Syntheses TLCK and pentamidine isethionate, potent trypsin inhibitors, strongly inhibit the growth of $E$. coli and macromolecular synthesis in $E$. coli ${ }^{10,11)}$ So, the effects of these compounds on the growth of $E$. coli K-12 IAM 1264 were examined. As shown in Fig. 5a, the effect of TLCK was dose-dependent, but its effect was temporary and reparable: the addition of $2 \mathrm{mM}$ TLCK completely suppressed the growth of $E$. coli during $2 \mathrm{~h}$. Thereafter, the growth gradually recovered and showed an exponential growth curve similar to the control. 


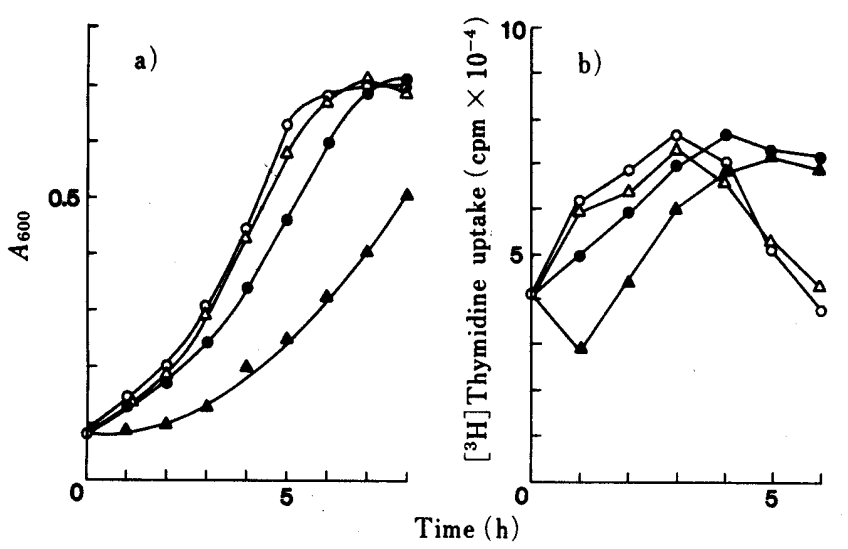

Fig. 5. Inhibitory Effects of TLCK on Growth of E. coli and on the Uptake of $\left[{ }^{3} \mathrm{H}\right]$ Thymidine into DNA, and the Effects of Reduced Glutathione

Experimental conditions and determination of inhibitory effects of TLCK on the growth of $E$. coli and on the uptake of $\left[{ }^{3} \mathrm{H}\right]$ thymidine into DNA were as described in Fig. 3. Reduced glutathione was concomitantly added with TLCK. a) Inhibitory effect on the growth of $E$. coli. b) Inhibitory effect on the uptake of $\left[{ }^{3} \mathrm{H}\right]$ thymidine into DNA. -O-, without TLCK; - - , with $1 \mathrm{mM} ;-\triangle-$, with $2 \mathrm{mM}$ of TLCK; $-\triangle$, with $2 \mathrm{mM}$ TLCK and $2 \mathrm{mM}$ reduced glutathione.

Figure 5B shows the effect of TLCK on the uptake of $\left[{ }^{3} \mathrm{H}\right]$ thymidine into DNA. As compared to the control, $1 \mathrm{mM}$ TLCK tentatively reduced the uptake of $\left[{ }^{3} \mathrm{H}\right]$ thymidine into DNA. However, the uptake recovered and reached a maximum after $4 \mathrm{~h}$. The addition of $2 \mathrm{mM}$ TLCK caused a rapid decrease in the uptake with recovery after $2 \mathrm{~h}$, and the profile of the latter uptake was similar to that of the control. A maximum uptake was seen after $5 \mathrm{~h}$. Inhibition of RNA synthesis by TLCK is recovered by reduced glutathione. ${ }^{1{ }^{1)}}$ As shown in Figs. 5a and 5b, the addition of the equimolar concentration of reduced glutathione completely abolished the effect of TLCK on the growth of $E$. coli and DNA synthesis. On the other hand, reduced glutathione ( $2 \mathrm{mM}$ ) had no effect on the inhibitory effects of GMCHA-OPh ${ }^{t} \mathrm{Bu}$ on either growth of $E$. coli or DNA synthesis (data not shown).

These results indicate that the effects of TLCK on the cell growth and the DNA synthesis markedly differ from those of GMCHA-OPh ${ }^{t} \mathrm{Bu}$.

The effects of pentamidine isethionate on the growth of $E$. coli and the uptake of $\left[{ }^{3} \mathrm{H}\right]$ thymidine are shown in Figs. $6 \mathrm{a}$ and $6 \mathrm{~b}$, respectively. Although pentamidine isethionate dose-dependently suppressed the growth of $E$. coli, its effect seemed to be reparable: transient and strong inhibition of the growth of $E$. coli was observed at $50 \mu \mathrm{M}$ pentamidine isethionate, but recovery was observed, and $E$. coli cells continued to grow exponentially. The effect of $100 \mu \mathrm{M}$ was similar to that at $54 \mu \mathrm{M} \mathrm{GMCHA}-\mathrm{OPh}^{t} \mathrm{Bu}$, while the effect of pentamidine isethionate seemed to be abolished after $8 \mathrm{~h}$. The addition of $200 \mu \mathrm{M}$ pentamidine isethionate completely suppressed the growth of $E$. coli for at least $8 \mathrm{~h}$, but after $24 \mathrm{~h}$ turbidity at $600 \mathrm{~nm}$ reached a maximum. On the other hand, GMCHA-OPh ${ }^{t} \mathrm{Bu}(90 \mu \mathrm{M})$ completely inhibited the cell growth for $24 \mathrm{~h}$.

The effect of pentamidine isethionate on the uptake of $\left[{ }^{3} \mathrm{H}\right]$ thymidine was also dose-dependent and transient. At $50 \mu \mathrm{M}$ it suppressed the uptake for $2 \mathrm{~h}$, thereafter, the uptake recovered and reached a maximum after $5 \mathrm{~h}$. Although the suppression of DNA replication caused by $100 \mu \mathrm{M}$ pentamidine isethionate continued for $5 \mathrm{~h}$, the effect

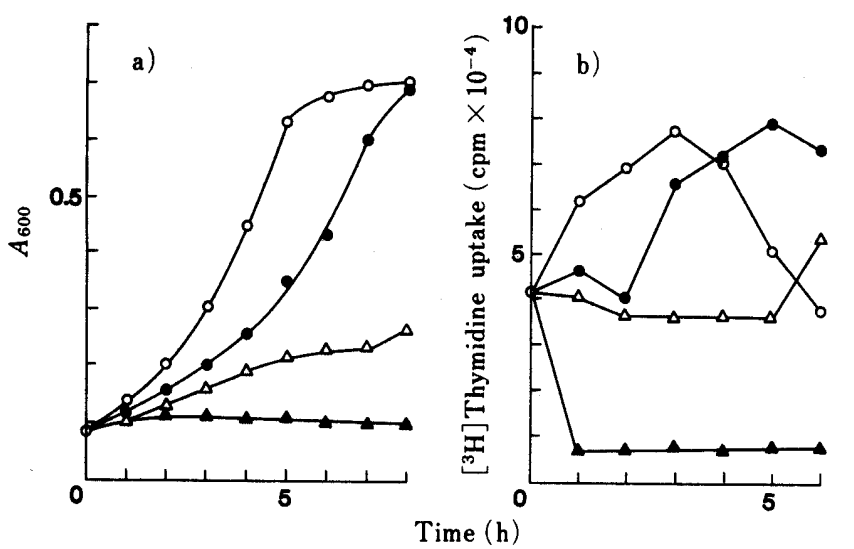

Fig. 6. Inhibitory Effects of Pentamidine Isethionate on the Growth of E. coli and on the Uptake of $\left[{ }^{3} \mathrm{H}\right]$ Thymidine into DNA

Experimental conditions, determination of inhibitory effects of pentamidine isethionate on growth of $E$. coli and the uptake of $\left[{ }^{3} \mathrm{H}\right]$ thymidine into DNA were as described in Fig. 3. a) Inhibitory effect on the growth of $E$. coli. b) Inhibitory effect on the uptake of $\left[{ }^{3} \mathrm{H}\right]$ thymidine into DNA. - $\mathrm{O}-$, without penamidine isethionate; - - with $50 \mu \mathrm{M} ;-\triangle-$, with $100 \mu \mathrm{M} ;-\triangle-$, with $200 \mu \mathrm{M}$ of pentamidine isethionate.

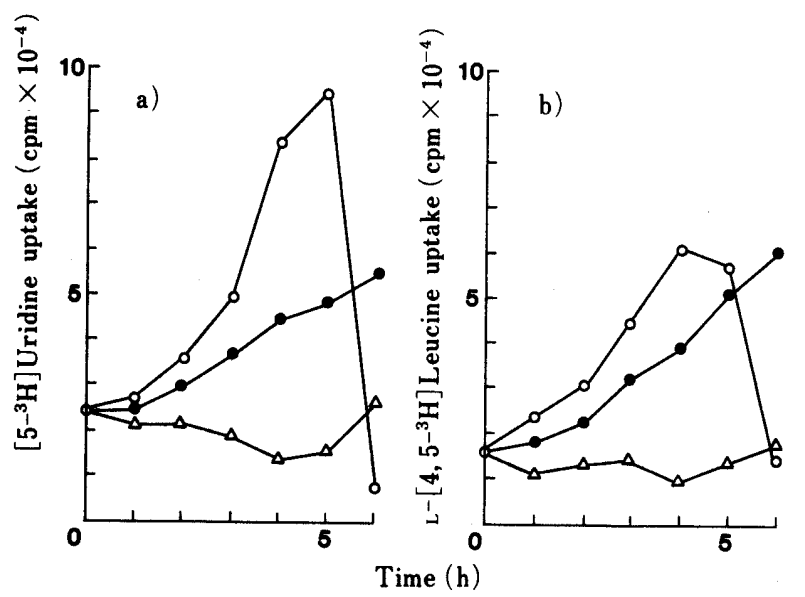

Fig. 7. Inhibitory Effects of Pentamidine Isethionate on RNA and Protein Syntheses

Experimental conditions were as described in Fig. 4. a) The inhibitory effect on the uptake of $\left[5-{ }^{3} \mathrm{H}\right]$ uridine into RNA. b) The inhibitory effect on the uptake of $\mathrm{L}-\left[4,5-{ }^{3} \mathrm{H}\right]$ leucine into protein. $-\mathrm{O}-$, without inhibitor; - - - , with $50 \mu \mathrm{M} ;-\triangle-$, with $100 \mu \mathrm{M}$ of pentamidine isethionate.

disappeared after $6 \mathrm{~h}$. A higher concentration of pentamidine isethionate $(200 \mu \mathrm{M})$ induced abrupt and marked reduction of DNA replication and the effect continued for at least $6 \mathrm{~h}$. These results seem to closely correlate with the effect of pentamidine isethionate on the growth of $E$. coli, moreover, these results indicate that the effects of pentamidine isethionate on the growth of $E$. coli and DNA synthesis differ from those of GMCHA-OPh ${ }^{t} \mathrm{Bu}$. The effects of pentamidine isethionate on RNA and protein syntheses were also dose-dependent (Figs. 7a and 7b) and similar to that on the cell growth (Fig. 6a).

\section{Discussion}

In this study, the effects of various esters of GMCHA on the growth of $E$. coli were examined by viable cell counting. Various esters suppressed the growth of $E$. coli but the effects were varied. The results shown in Table I indicate that the inhibitory effects of GMCHA esters are markedly affected by the species and position of substitution on the phenyl nucleus of GMCHA phenyl esters, and the effects 
seem to correlated with the hydrophobic or steric factor of the substituent, although details were not examined in this paper.

Prouty and Goldberg ${ }^{10)}$ reported that various protease inhibitors including potent trypsin inhibitors such as TLCK and aromatic diamidines, inhibited protein breakdown in starving $E$. coli cells at doses which did not inhibit the growth in glucose minimum medium, and higher concentrations of TLCK markedly reduced the growth. Rossman et $a l .{ }^{11)}$ examined the inhibitory effect of chloromethyl ketone protease inhibitors on $\beta$-galactosidase induction, growth, RNA synthesis and protein synthesis in E. coli, and stated that at least some biological effects of the chloromethyl ketones were due to activities other than the inhibition of a proteinase, and their effects were recovered by reduced glutathione. So, the effects of GMCHA-OPh ${ }^{t} \mathrm{Bu}$ on the growth, and DNA, RNA and protein syntheses were examined as a representative of various GMCHA esters, and the results were compared with those of TLCK and pentamidine isethionate. TLCK abruptly and strongly suppressed the growth and the DNA synthesis in E. coli. However, its effects were transient, and in a short time the growth and DNA replication recovered to the control level, and the effects were abolished by the addition of reduced glutathione. Pentamidine isethionate strongly inhibited the growth, but recovery occurred in a short time. Although DNA synthetic activity was markedly reduced when pentamidine isethionate was added, after an hour signs of recovery were observed and synthetic activity began to return to normal. On the other hand, GMCHA-OPh ${ }^{t} \mathrm{Bu}$ strongly and time-dependently inhibited the growth and the DNA replication in $E$. coli, and its inhibitory effects were not affected by reduced glutathione. These results indicate that the inhibitory effects of GMCHA-OPh ${ }^{t} \mathrm{Bu}$ differ from those of TLCK and pentamidine isethionate. The inhibition mechanisms of TLCK and pentamidine isethionate are complicated and unclear at this time. The inhibition of DNA synthesis by GMCHA-OPh ${ }^{t} \mathrm{Bu}$ preceded that of the growth of $E$. coli. These results strongly suggest that the inhibitory effect of GMCHA-OPh ${ }^{t} \mathrm{Bu}$ on the grow'th is caused by the suppression of DNA replication, and the latter effect is due to inhibition of a specific trypsin-like proteinase(s) involved in DNA replication. To confirm the suggestion we examined the inhibitory effects of GMCHA$\mathrm{OPh}^{t} \mathrm{Bu}$ with synchronized $E$. coli cells, and found a trypsin-like proteinase which participates in the onset of DNA synthesis. The inhibitory effects of TLCK and pentamidine isethionate on the trypsin-like proteinase are weakly or not seen [M. Kato, T. Irisawa, Y. Morimoto and M. Muramatu unpublished].

GMCHA-OPh ${ }^{t} \mathrm{Bu}$ and pentamidine isethionate strongly inhibited RNA and protein syntheses in E. coli. Their inhibition mechanisms are unclear at this time.

\section{References}

1) A. L. Goldberg and A. C. St. John, Annu. Rev. Biochem., 45, 747 (1976).

2) D. W. Mount, Annu. Rev. Genet., 14, 279 (1980).

3) A. C. St. John and A. L. Goldberg, J. Bacteriol., 143, 1223 (1980).

4) W. Wickner, Annu. Rev. Biochem., 48, 23 (1979).

5) B. D. Davis and P. C. Tai, Nature (London), 283, 433 (1980).

6) C. G. Miller, Annu. Rev. Microbiol., 29, 485 (1975).

7) D. Cavard and C. Lazdunski, Eur. J. Biochem., 96, 525 (1979).

8) L. K. Bowles and J. Konisky, J. Bacteriol., 145, 668 (1981).

9) J. W. Roberts, C. W. Roberts and L. Craig, Proc. Natl. Acad. Sci. U.S.A., 75, 4714 (1978).

10) W. F. Prouty and A. L. Goldberg, J. Biol. Chem., 247, 3341 (1972).

11) T. Rossman, C. Norris and W. Troll, J. Biol. Chem., 249, 3412 (1974).

12) K. Ito, J. Bacteriol., 132, 1021 (1977).

13) K. Ito, Biochem. Biophys. Res. Commun., 82, 99 (1978).

14) M. S. Meyn, T. Rossman and W. Troll, Proc. Natl. Acad. Sci. U.S.A., 74, 1152 (1977)

15) M. Muramatu and S. Fujii, Biochim. Biophys. Acta, 242, 203 (1971).

16) M. Muramatu and S. Fujii, Biochim. Biophys. Acta, 268, 221 (1972).

17) S. Mori, Y. Kozaki, M. Kato, A. Tendo, Y. Kikawa, H. Sekine and M. Muramatu, J. Biochem. (Tokyo), 95, 1617 (1984).

18) Y. Kozaki, T. Amoh, N. Yamaguchi and M. Muramatu, Biochim. Biophys. Acta, 1014, 120 (1989).

19) B. D. Davis and E. S. Mingioli, J. Bacteriol., 60, 17 (1950).

20) D. Joseleau-Petit, F. Képès and A. Képès, Eur. J. Biochem., 139, 605 (1984). 